\title{
Mechanism of formation, mineralogy and geochemistry of the ooidal ironstone of Djebel Had, northeast Algeria
}

\author{
Hamida Diab1*, Abdelmadjid Chouabbi2, ERnest Chi Fru3, JAmEl-Eddine Nacer4 \& Mark KreKeler5 \\ 1Laboratory of Geodynamics and Natural Resources - LGRN - Badji Mokhtar University, National Company of Iron Mines \\ SOMIFER, Tebessa, Algeria. E-mail: * \\ 2Laboratory of Geodynamics and Natural Resources - LGRN - Badji Mokhtar University, Annaba, Algeria.
}

3School of Earth and Ocean Sciences, University of Cardiff, United Kingdom.

4Nuclear Research Center Draria -CRND- Algiers, Algeria.

5Department of Geology, University of Miami, Hamilton Ohio, USA.

*diabhamida@rocketmail.com

\begin{abstract}
The Djebel Had Ironstone (DHIS), an eight meter thick stratiform sedimentary iron formation, forms part of the important mining district of south Tebessa, in northeastern Algeria. Stratigraphic, lithological, structural and metallogenic similarities, suggest the DHIS may extend further into southwestern Tunisia. We show that mineralization occurs as layers of ooidal ironstones and inter-laminated iron marl within mid-Eocene gypsiferous marls. The more or less rounded 0.1-2.0 mm brownish-blackish ooids, are composed of goethite, limonite, hematite, with traces of magnetite and piemontite. The grains display a smooth outer surface bound by an argilo-ferruginous layer embedded in siliceous-calcite cement. They are unusually friable, crumbling at the slightest shock. A high total iron (FeT) content of $50.12 \%$, is dominated by up to $71.06 \%$ iron hydroxide $(\mathrm{FeO}(\mathrm{OH})$. Much of the iron is present as goethite, a common feature of iron-rich ooids of North African origin. However, the lack of prominent chlorite minerals suggest the DHIS is not of a detrital origin. Instead, a negligible Ti and Al oxide concentration suggest a chemical provenance for the DHIS. The data suggest that ferruginous conditions developed in a potentially restricted/semi-restricted continental shelf margin where seafloor redox was sensitive to the alternating cycles of sea level change. We propose a new mechanism for the formation of ooidal ironstones, associated with shelf surface water eutrophication, bottom water anoxia promoted by sea level rise and the weathering of iron phosphate-rich rocks. Phosphorus and cerium enrichment, coupled to reconstructed redox depositional conditions and sediment mineralogy, suggest that intense biomass production stimulated the deoxygenation of shelf bottom waters and the deposition of the DHIS beneath a ferruginous water column.
\end{abstract}

Key words: Redox; weathering, iron formation; mid-Eocene; Tebessa; North Africa 